\title{
Oil Price and Financial Sector in Eastern Europe: A Panel Data Investigation
}

\author{
Alexandra Lavinia Horobet', Georgiana Maria Vrinceanu1, and \\ Ana-Maria Barsan² \\ ${ }^{1}$ The Bucharest University of Economic Studies, Bucharest \\ ${ }^{2}$ The University of Bucharest, Bucharest
}

\section{Abstract}

Our paper investigates the exposure to oil price fluctuations of financial companies listed on stock exchanges from Eastern European countries: Romania, Bulgaria, Hungary, Poland, Czech Republic, Slovakia, Slovenia and Croatia. Using monthly datasets covering the period from February 2010 to February 2018, we examine the relationship between stock prices of these financial companies, oil prices and other macroeconomic variables, such as local stock indices, a European stock index designed to measure the performance of companies from this region (FTSE Europe), an indicator of a country's international price competitiveness (NEER), interest rates

Corresponding Author: Georgiana Maria Vrinceanu georgiana.vrinceanu_2013@ yahoo.com

Received: 17 November 2019 Accepted: 6 January 2019 Published: 12 January 2020

Publishing services provided by Knowledge E

(c) Alexandra Lavinia Horobet et al. This article is distributed under the terms of the Creative Commons Attribution License, which permits unrestricted use and redistribution provided that the original author and source are credited.

Selection and Peer-review under the responsibility of the EBEEC Conference Committee.

\section{G OPEN ACCESS} and an indicator of systemic stress, named Composite Indicator of Systemic Stress (CISS). Applying the panel data methodology, our results indicate an unexpected fact. We show that there is a significant exposure of financial companies to the oil price fluctuations. We discover that in the financial sector, high oil prices may have indeed positive effects on the stock prices. The price of oil has a higher impact on the stock prices of financial companies than we expected and it proved be a risk factor for this sector. Our results indirectly highlight the pervasive exposure of economies from the region to risk factors through the financial sector channels, which raises serious challenges from the perspective of macroeconomic and financial policies.

Keywords: oil price, financial sector, panel data analysis.

\section{Introduction}

Crude oil is considered nowadays the most valuable resource for the global economy. Falling oil prices impact the monetary, fiscal and structural policies based on whether a country is an oil importer or an oil exporter. Between 2011 and 2014, the price of Brent crude oil was relatively stable at around \$105 per barrel and since June 2014 it has collapsed sharply. The lowest level in twelve years was reached in February 2016 when it crashed close to $\$ 30$ per barrel and until the end of this year, the price of oil has rebounded vigorously [1]. After these episodes, the oil price has remained rather stable and a moderate growth is expected for the immediate future. 
The fluctuations in oil prices tend to have a decisive impact on the world economy, on the global inflation rate, on the exchange rates and on the revenue of the companies as well. Taking into account the significance of oil as a global resource and its shortterm inelasticity of demand, notable research has focused on the impact of oil price fluctuations on macroeconomic variables, such as inflation, exchange rates and GDP growth rates. Also, a concerning issue in financial markets in recent years is the fact that Brent crude oil price and stock prices seem to be rather well correlated. Thus, the purpose of this paper is to investigate the exposure of financial companies from Eastern Europe to oil price fluctuations, given the region's countries status of net oil importers.

Building on the assumption that a stock's market value represents the sum of the discounted expected future cash flows provided to investors by the issuer of the stock, as long as these future cash flows are influenced by macroeconomic developments at the level of price changes, then stock values are linked to oil prices.

In our analysis we have included Eastern European countries that are crude oil importing countries; as a consequence, the oil price changes affect their private consumption through different channels, direct and indirect. For example, an increase in oil prices influences directly the households' purchasing power through charging higher prices for buying oil-based energy products. The dependence of the European countries on oil imports has considerably grown in the last twenty years and these countries spend every year billions of euros on oil imports. More specifically, it seems that crude oil dominates the imports of the European countries in energy products with a share of 70 percent in the first semester of 2018 [2].

In the investigated region of Europe there are countries which have different financial sector development levels. Some of these analyzed countries are still in the transition process and other countries seem to have already completed reform changes in the financial sector [3]. In other words, there are important differences in the financial sector development levels among these eight Eastern European countries. These differences could be explained principally by the degree of government policies and reforms implemented in order to modernize the financial sector. Also, the fall of the US financial market at the end of 2007 had a negative impact on the global economic and financial system. The countries from Eastern Europe were indeed particularly severely affected by the financial and economic crisis that influenced negatively the entire world. Furthermore, the global financial crisis revealed substantial gaps in the theoretical and empirical frameworks for monitoring systemic risk in the Eastern European financial system.

Our paper is structured as follows. Section 2 presents the empirical literature on the subject of the relationship between oil price changes and stock returns. Section 3 
describes the data and the methodology. Our findings and results are presented and then discussed in Section 4. Finally, Section 5 concludes.

\section{Literature Review}

The relationship between oil price changes and macroeconomic variables represents a relatively recent topic in the literature and it has been seldom debated. The first author who investigated this type of relationship was Hamilton [4]. His paper demonstrates that oil price changes regularly had a significant impact on the US economic activity in the period between WWII and the 1980's. The author states that seven out of the eight US recessions corresponded with oil price surges. Moreover, he claimed that since then, the relationship between oil price changes and economic conditions had become more systematic.

It is particularly important to point out that the empirical literature on this subject is still growing and also, most studies have focused on the impact of oil price changes on stock market returns. The current empirical evidence demonstrates that oil price changes coincide with fluctuations in stock prices, despite the rather mixed results. Some authors like Hamao [5], Kaneto and Lee [6], Huang et al. [7], Jones and Kaul [8], Cong et al. [9] or Jammazi and Aloui [10] found no relationship between oil price changes and stock market returns. On the other hand, other authors like Sadorsky [11] or Ciner [12] reported opposite findings. These authors discovered that oil price movements proved to be imperative for explaining the stock market returns.

Until now, the investigation of the effects of oil price changes on the stock market industrial sectors was quite silent even if it is absolutely necessary considering the fact that each industry may display specific responses to oil price movements and, as long as these responses are present, investors must take them into consideration in the form of risk premiums. Moreover, the aggregate stock market indices from different countries are not able to describe the comprehensive relationship between oil price changes and stock market returns and an investigation on the stock market industrial sector level would be greatly helpful. Some notable examples of studies on the impact of oil price changes on the stock market industrial sectors are: Arouri and Nguyen [13], Arouri [14], Degiannakis et al. [15], Elyasiani et al. [16], Narayan and Sharma [17] and Scholtens and Yurtsever [18]. Regarding the financial sectors, the results are inconclusive. Overall, their findings showed that there are positive effects of the oil price changes on oil-related and oil-substitute sectors, negative effects on oil-using sectors and insignificant effects on non-oil-related sectors, such as financial sector. Gogineni [19] justified these findings 
and explained them by the supply chain dependency to oil markets which is the key to demonstrating the impact of oil price movements in any sector.

Arouri and Nguyen [13] examined the link between oil price changes and European stock returns using the Dow Jones Stoxx 600 and 12 industrial sector indices from European countries. They discovered that the Food and Beverages, Health Care and Technology sectors display negative responses to oil price increases, while other sectors like the Financial, Oil and Gas, Industrials, Basic Materials and Personal and Household Goods sectors display positive responses. One year later, in a subsequent study, Arouri [14] found that the Oil and Gas sector exhibits a positive response to oil price movements, while the Financials and Consumer Goods sectors exhibits a negative response to oil price movements.

Elyasiani et al. [16] investigated the relationship between oil price fluctuations and industry stock returns of thirteen US industries. The authors divided the industries in four main categories: oil-users, oil-substitute, oil-related and financial industries. They showed that oil price changes have a direct effect on oil-related and oil-substitute industries, while this effect proved to be indirect for the oil-users and financial industries. In other words, the effects seemed to be positive for the oil-substitute and oil-related industries and negative for the other categories.

Narayan and Sharma [17] investigated the relationship between oil price and the stock returns of 560 US companies listed on the NYSE using a GARCH model. Their findings reveal the fact that oil price changes have asymmetric effects on stock returns, considering the sector they are listed in. While the sectors like Supply, Manufacturing, Food, Chemical, Medical, Computer, Transportation, Banking, Real Estate and General Services exhibit a negative response to positive oil price shocks, other sector like the Energy proved to have a positive response to positive oil price shocks. For the Electricity, Engineering and Financial sectors, the results proved to be inconclusive

Scholtens and Yurtsever [18] discovered that the impact of oil prices shocks on 38 stock markets at the industry level in European countries considerably vary along the European industries over the period 1983-2007. Their paper showed that most stock market industries would benefit from the negative oil price changes.

So far, only few studies have focused on analyzing the impact of oil price changes on the stock market industrial sectors from Eastern Europe. Moreover, there is no study focusing only on one stock market industrial sector, to our knowledge. Researchers were not interested on examining this type of relationship in countries from this region as compared to other regions like Western Europe or US. For example, Asteriou and Bashmakova [20] investigated the impact of oil price changes on stock market returns 
in the Central and Eastern European countries and found that oil price changes impact negatively the stock market returns. Mohanty et al. [21] examined the link between oil price changes and stock returns of oil and gas companies in CEE countries. Their findings revealed no representative association between them over the period from 1998 to 2010.

Concerning the studies focusing on the investigation of the effects of oil price changes on the stock market returns or on the economic growth that used the same methodology, the panel data methodology, some examples are: Akinlo and Apanisile [22], Asteriou and Bashmakova [20] and Santillán-Salgado et al. [23]. Akinlo and Apanisile [22] investigated the impact of the volatility of oil price on economic growth in 20 sub-Saharan African countries from the period of 1986-2012. Another study, Santillán-Salgado et al. [23], analyzed the sensitivity of the stock market returns of Argentina, Brazil, Chile, Colombia, Mexico, and Peru to international oil price fluctuations from 2000 to 2015. Also, Faff and Brailsford [24] used GMM (Generalized Method of Moments) techniques in order to analyze the restrictions required by a two-factor (market and oil price) pricing model. Their research was undertaken over the period from 1983 to 1996 using a sample of industry sector returns from Australia.

Considering these, our paper contributes to the literature regarding the relationship between oil price changes and stock market industrial sectors from Eastern Europe by showing that financial companies from the region are exposed to various sources of systemic risk in a pervasive manner; moreover, the specific exposure to changes in oil prices points towards the financial sector role as risk-trigger for the real economy, which raises numerous concerns regarding financial and macroeconomic stability.

\section{Data and Research Methodology}

For this research we used monthly datasets covering the period from February 2010 to February 2018 and we included in our analysis the following eight Eastern European countries: Bulgaria, Croatia, Czech Republic, Hungary, Poland, Romania, Slovakia and Slovenia, all of them EU members. We examined the relationship between stock prices of 32 financial companies listed on stock exchanges from these Eastern European countries, oil prices and other macroeconomic variables, such as local stock market indices, a European stock index designed to measure the performance of companies from this region (FTSE Europe), an indicator of a country's international competitiveness in terms of the foreign exchange market (NEER), United States 1-Month Bond Yield and an indicator of systemic stress, named Composite Indicator of Systemic Stress (CISS). 
We have selected 32 financial companies listed on stock exchanges from these eight Eastern European countries based on the maximum data availability for the monthly frequency for the period February 2010 to February 2018. In the case of Croatia, we found only one financial company with available data. Also, we have included the United States 1-Month Bond Yield as a global indicator of changes in interest rates.

We have included in our analysis the following local stock market indices: BSE SOFIX for Bulgaria, CROBEX for Croatia, FTSE for Hungary and Czech Republic, WIG for Poland, BET for Romania, SAX for Slovakia and Blue-Chip SBITOP for Slovenia. Table 1 presents the set of stock market indices employed for each Eastern European country in our sample.

For our research we have selected only the financial companies with available data for our sample period. We have chosen the largest eight Bulgarian listed companies by market capitalization with available data for the sample period, only one financial listed company from Croatia, three financial listed companies from Czech Republic, two financial listed companies from Hungary, four financial companies from Poland, nine Romanian financial companies, two financial companies from Slovakia and other three financial companies from Slovenia. The financial companies' stock prices were collected from Bloomberg. Table 2 presents each selected listed company from the financial sector, their last declared market capitalization and the percentage in the total stock exchange market capitalization of the country.

TABLE 1: Data description.

Country
Bulgaria
Croatia
Czech Republic
Hungary
Poland
Romania
Slovakia
Slovenia

Local Stock Market Indices
BSE SOFIX
CROBEX
FTSE Czech Republic
FTSE Hungary
WIG Poland
BET
SAX
Blue-Chip SBITOP
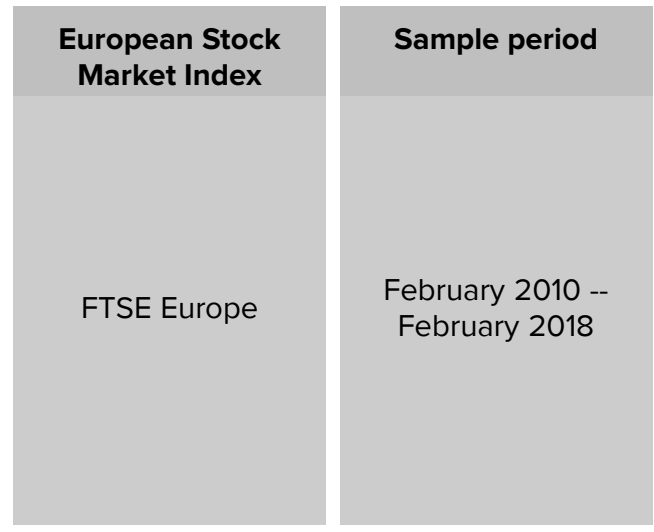

Source: Authors' own work.

One of the macroeconomic variables used in our analysis is the Nominal Effective Exchange Rate (NEER). This index indicates the appreciation or the depreciation of the national currency against the currencies of several selected trading partners for a certain period of time. NEER data was collected from the International Financial Statistics (IFS) dataset portal of the International Monetary Fund. The rationale behind the use of this 
variable allows us to introduce in the model the impact of changes in the country's price competitiveness against its major trading partners on financial companies' stock returns. According to the Bank for International Settlements, the calculation method of the Nominal Effective Exchange Rate (NEER) is based on the following formula:

$$
N E E R^{t}=\prod_{i=1}^{N}\left(e_{K M, i}^{t}\right)^{w_{i}}
$$

Where $N$ denotes the number of competitor countries in the group of trading partners, $e_{K M, i}^{t}$ represents an index of the average exchange rate of the currency of KM vis--à-vis the partner country $i$ in the period $t$ (expressed in terms of the domestic currency unit per unit of a foreign currency), and $w_{i}$ represents the trade weight assigned to the currency of trading partner $i$.

Another macroeconomic variable used for our research is CISS (Composite Indicator of Systemic Stress). This indicator aims to measure the level of systemic stress, the instability in the financial system as a whole. This financial stress index is computed for the euro area as a whole and it takes into consideration the five most essential segments of a financial system: the sector of bank and non-bank financial intermediaries, money markets, securities markets and foreign exchange markets. The monthly data of this index was collected from Statistical Data Warehouse of the European Central Bank.

In our research we have employed the companies' stock market performance depending on their stock market returns. However, our model does not use a raw measure of performance, such as stock returns, but we used instead a risk-adjusted measure of stock performance, i.e. the Sharpe Ratio. When interpreting the value of the Sharpe ratio, we have to take into account the fact that the higher the value of the Sharpe ratio (SR), the more attractive the risk-adjusted return. The general formula for the Sharpe ratio (SR) is the following:

$$
S R=\frac{R_{t}-R_{f}}{\sigma_{t}}
$$

Where $R_{t}$ represents the financial company's return, $R_{f}$ denotes the risk free rate and $\sigma_{t}$ represents the standard deviation of the returns. For our research purposes, the Sharpe ratio is calculated based on monthly returns of financial companies' stock prices, $R_{f}$ is the United States 1-Month Bond Yield and $\sigma_{t}$ is the daily average standard deviation of returns that is, afterwards adjusted to the monthly level.

In order to identify the relationship between stock prices of financial companies, oil prices and other macroeconomic variables, we used the panel data as econometric model. This type of methodology proved to be more capable to identify and measure the effects that are not effortlessly noticeable in time-series or in pure cross-section data. 
TABLE 2: Selected financial companies and their market capitalization (in USD millions, 2018).

\begin{tabular}{|c|c|c|c|c|}
\hline Country & $\begin{array}{c}\text { Market } \\
\text { capitalization for } \\
\text { countries }(\$ \mathrm{~m})\end{array}$ & $\begin{array}{l}\text { Financial companies in } \\
\text { our sample }\end{array}$ & $\begin{array}{l}\text { Companies' } \\
\text { market } \\
\text { capitalization } \\
(\$ \mathrm{~m})\end{array}$ & $\begin{array}{c}\text { Share of } \\
\text { countries' market } \\
\text { capitalization \% }\end{array}$ \\
\hline \multirow[t]{8}{*}{ Bulgaria } & 4,978 & CB First Investment Bank & 231 & $4.640 \%$ \\
\hline & & Eurohold Bulgaria & 217 & $4.359 \%$ \\
\hline & & $\begin{array}{l}\text { CB Central Cooperative } \\
\text { Bank }\end{array}$ & 115 & $2.310 \%$ \\
\hline & & $\begin{array}{l}\text { CB Bulgarian American } \\
\text { Credit Bank }\end{array}$ & 92 & $1.848 \%$ \\
\hline & & Bulgarian Real Estate Fund & 44 & $0.884 \%$ \\
\hline & & Bulland Investments & 10 & $0.201 \%$ \\
\hline & & FairPlay Properties & 10 & $0.201 \%$ \\
\hline & & Aktiv Properties & 9 & $0.181 \%$ \\
\hline Croatia & 20,392 & Zagrebacka Banka & 3,091 & $15.16 \%$ \\
\hline \multirow{3}{*}{$\begin{array}{l}\text { Czech } \\
\text { Republic }\end{array}$} & 55,802 & Erste Group Bank AG & 16,641 & $29.822 \%$ \\
\hline & & Komercni Banka & 7,884 & $14.129 \%$ \\
\hline & & Vienna Insurance AG & 3,544 & $6.351 \%$ \\
\hline \multirow[t]{2}{*}{ Hungary } & 26,748 & Takarek Mortgage Bank & 169 & $0.632 \%$ \\
\hline & & $\begin{array}{l}\text { Forras Vagyonkezelesi } \\
\text { Befektetsi }\end{array}$ & 46 & $0.172 \%$ \\
\hline \multirow[t]{4}{*}{ Poland } & 299,313 & $\begin{array}{l}\text { Bank Polska Kasa Opieki } \\
\text { SA }\end{array}$ & 7,921 & $2.646 \%$ \\
\hline & & ING Bank Slaski SA & 6,735 & $2.250 \%$ \\
\hline & & mBank SA & 4,865 & $1.625 \%$ \\
\hline & & Bank Millennium SA & 3,040 & $1.016 \%$ \\
\hline \multirow[t]{9}{*}{ Romania } & 39,098 & Erste Group Bank AG & 16,641 & $42.562 \%$ \\
\hline & & Banca Transilvania & 2,474 & $6.328 \%$ \\
\hline & & $\begin{array}{l}\text { BRD Groupe Societe } \\
\text { Generale SA }\end{array}$ & 2,210 & $5.652 \%$ \\
\hline & & SIF Oltenia SA & 290 & $0.742 \%$ \\
\hline & & SIF Moldova SA & 287 & $0.734 \%$ \\
\hline & & SIF Banat Crisana SA & 264 & $0.675 \%$ \\
\hline & & SIF Muntenia & 116 & $0.297 \%$ \\
\hline & & Patria Bank & 58 & $0.148 \%$ \\
\hline & & $\begin{array}{l}\text { Fondul Oamenilor de } \\
\text { Afeceri Bucuresti }\end{array}$ & 1 & $0.002 \%$ \\
\hline \multirow[t]{2}{*}{ Slovakia } & 5,440 & Vseobec Uver B & 2,645 & $48.621 \%$ \\
\hline & & Otp Banka & 32 & $0.588 \%$ \\
\hline \multirow[t]{3}{*}{ Slovenia } & 5,233 & Zavarovalnica & 878 & $16.778 \%$ \\
\hline & & Pozavar Valnic & 307 & $5.867 \%$ \\
\hline & & KD Group & 228 & $4.357 \%$ \\
\hline
\end{tabular}

Sources: The World Bank, the national stock exchanges and Investing.com.

Moreover, panel data models offer less collinearity among the explanatory variables 
and more variability. There are another recent studies on this topic that used the same methodology, such as Asteriou and Bashmakova [20], Akinlo and Apanisile [22] and Santillán-Salgado et al. [23].

We estimated panel equations parameters using the Eviews software program, based on the following general equation:

$$
Y_{i t}=\alpha+\beta_{i t} X_{i t}^{\prime}+\delta_{i t}+\gamma_{i t}+\varepsilon_{i t}
$$

Where $Y_{i t}$ is the dependent variable represented by the Sharpe Ratio of the companies' stock prices, $i$ denoting firms (the cross-section dimension) and $t$ denoting time, $\alpha$ is is the overall constant of the model that captures the effects of those variables that are constant over time, $\beta_{i t}$ represents the exposure coefficients, $X_{i t}^{\prime}$ is a vector which includes independent variables: oil price, local stock market index, European stock market index, NEER and CISS, $\delta_{i t}$ and $\gamma_{i t}$ capture the cross-section specific fixed effects and $\varepsilon_{i t}$ represents the error terms.

We have considered four panel specifications: no effects, cross-section fixed effects, period fixed effects and cross-section and period fixed effects. These panel specifications were estimated using GMM (Generalized Method of Moments), an estimation that provides a straightforward technique for testing the specifications of our proposed model. The first considered panel specification is the one with no effects, a highly restrictive panel specification which ignores all the differences in coefficients across time or countries. The cross-section fixed effects panel specification permit the intercept to vary across the financial companies, while the period fixed effects permit the intercept to vary across time. The last panel specification allows the intercept to vary across both financial companies and time. These approaches induce the possibility of heterogeneity at sample level. Overall, 20 panel equations were estimated for this research.

Firstly, we run the equation with all variables. Secondly, we excluded only the local stock market index. Then, we run without the FTSE Europe, then we excluded both stock market indices and after that, we eliminated the NEER. We did so for all four panel specifications. The results are presented and discussed in the next Section.

\section{Main Results and Discussions}

The results are presented by firstly showing and explaining the results for each panel specification, followed by comparing the panel specifications. The results of all our estimations are shown in Table 3. For all panel specifications we interpret and discuss only statistically significant coefficients at least at 5 percent level. 
When we include all the variables in the equation we notice statistically significant regression coefficients for both stock market indices and for the US 1-Month Bond Yield. Next, we eliminate the local stock market index from our equation and now we notice statistically significant regression coefficients for all variables, except CISS. The fact that oil price is a statistically significant independent variable is somehow surprising because this demonstrates that oil price changes impact stock prices of financial companies, which is an unexpected result that might indicate the exposure of the financial sector to real economy risk factors. When we exclude only the European stock index from the equation and include the local stock market index, we have significant coefficients for the price of oil, local stock market index and United States 1-Month Bond Yield. This time, NEER does not present a statistically significant coefficient, but again, significant coefficients for the oil price remain. This variable seems to be more and more important and proved to have a higher influence on the stock prices of the financial companies than we predicted since now. In the moment when we decide to remove both stock market indices from the equation, we remark statistically significant regression coefficients for all variables, which might suggest that exposure to oil price changes, interest rates and currency risk is pervasive. Our last estimation under the no effects specification implies the elimination of the NEER from the equation. In this case, the results show statistically significant regression coefficients for both stock market indices and at the US 1-Month Bond Yield.

The second panel specification considered in our model is the fixed cross-effects specification. This type of panel specification permits the intercept $\alpha$ to vary depending on the company. These panel estimations take into consideration the probable existence of cross-section heteroskedasticity through the usage of the cross section weights. Including all the variables in the equation we notice statistically significant regression coefficients for both the stock market indices (local and European) and at the US 1-Month Bond Yield. When we remove the local stock market index from the equation, we remark significant coefficients for all variables, except CISS, as in the case of the first panel specification, namely no effects. Then, when eliminating the EU stock market index, the results present significant coefficients for the price of oil, at the local stock market index and at the US 1-Month Bond Yields. Oil price displays statistically significant regression coefficients in almost all situations. It is clearly that high oil prices may have indeed positive effects on the stock prices of the financial companies. When we remove both stock market indices from the equation we notice significant coefficients for all variables that remain in the equation. We face with an identical case as the one detailed above from the panels with no effects. Finally, excluding the NEER from our equation, we notice 
TABLE 3: Panel estimation results.

\begin{tabular}{|c|c|c|c|c|c|c|c|c|c|}
\hline $\begin{array}{l}\text { Panel } \\
\text { Specification }\end{array}$ & $\alpha$ & OIL & $\begin{array}{l}\text { Stock } \\
\text { Index }\end{array}$ & EU Index & NEER & US-1M & CISS & Adj. $R^{2}$ & J-statistic \\
\hline No effects & -0.198 & 0.267 & 6.757 & 2.146 & 0.935 & -0.048 & 0.186 & 0.310 & 0.000 \\
\hline No effects & -0.197 & 0.707 & & 7.316 & 10.719 & -0.051 & 0.019 & 0.219 & 0.000 \\
\hline No effects & -0.196 & 0.575 & 7.860 & & 0.527 & -0.048 & 0.110 & 0.304 & 0.000 \\
\hline No effects & -0.185 & 2.842 & & & 17.405 & -0.055 & -0.563 & 0.100 & 3099.000 \\
\hline No effects & -0.198 & 0.264 & 6.802 & 2.137 & & -0.048 & 0.181 & 0.311 & 0.000 \\
\hline $\begin{array}{l}\text { Fixed } \\
\text { cross-effects }\end{array}$ & -0.198 & 0.266 & 6.769 & 2.138 & 0.895 & -0.048 & 0.187 & 0.315 & 0.000 \\
\hline $\begin{array}{l}\text { Fixed } \\
\text { cross-effects }\end{array}$ & -0.197 & 0.707 & & 7.314 & 10.816 & -0.051 & 0.020 & 0.223 & 0.000 \\
\hline $\begin{array}{l}\text { Fixed } \\
\text { cross-effects }\end{array}$ & -0.196 & 0.572 & 7.872 & & 0.468 & -0.048 & 0.111 & 0.309 & 0.000 \\
\hline $\begin{array}{l}\text { Fixed } \\
\text { cross-effects }\end{array}$ & -0.185 & 2.841 & & & 17.537 & -0.055 & -0.562 & 0.103 & 3068.000 \\
\hline $\begin{array}{l}\text { Fixed } \\
\text { cross-effects }\end{array}$ & -0.198 & 0.263 & 6.812 & 2.129 & & -0.048 & 0.181 & 0.315 & 0.000 \\
\hline $\begin{array}{l}\text { Period fixed } \\
\text { effects }\end{array}$ & 43.465 & -168.907 & 6.030 & -138.873 & 0.816 & 188.125 & 482.192 & 0.440 & 0.000 \\
\hline $\begin{array}{l}\text { Period fixed } \\
\text { effects }\end{array}$ & 32.704 & -216.814 & & 77.815 & 7.352 & 147.116 & 315.329 & 0.391 & 0.000 \\
\hline $\begin{array}{l}\text { Period fixed } \\
\text { effects }\end{array}$ & 41.109 & -152.569 & 6.005 & & 0.895 & 176.546 & 499.343 & 0.440 & 0.000 \\
\hline $\begin{array}{l}\text { Period fixed } \\
\text { effects }\end{array}$ & 33.964 & -226.130 & & & 7.322 & 153.334 & 305.289 & 0.391 & 0.000 \\
\hline $\begin{array}{l}\text { Period fixed } \\
\text { effects }\end{array}$ & 44.346 & -166.250 & 6.069 & -143.210 & & 192.432 & 482.457 & 0.440 & 0.000 \\
\hline $\begin{array}{l}\text { Cross- } \\
\text { section and } \\
\text { period fixed } \\
\text { effects }\end{array}$ & 46.364 & -172.917 & 6.031 & -136.697 & 0.809 & 204.053 & 458.383 & 0.446 & 0.000 \\
\hline $\begin{array}{l}\text { Cross- } \\
\text { section and } \\
\text { period fixed } \\
\text { effects }\end{array}$ & 33.649 & -218.486 & & 78.919 & 7.451 & 152.329 & 307.322 & 0.397 & 0.000 \\
\hline $\begin{array}{l}\text { Cross- } \\
\text { section and } \\
\text { period fixed } \\
\text { effects }\end{array}$ & 42.954 & -156.685 & 6.007 & & 0.888 & 187.212 & 475.384 & 0.446 & 0.000 \\
\hline $\begin{array}{l}\text { Cross- } \\
\text { section and } \\
\text { period fixed } \\
\text { effects }\end{array}$ & 35.332 & -228.000 & & & 7.421 & 160.651 & 297.148 & 0.397 & 0.000 \\
\hline $\begin{array}{l}\text { Cross- } \\
\text { section and } \\
\text { period fixed } \\
\text { effects }\end{array}$ & 45.994 & -170.078 & 6.070 & -140.471 & & 202.138 & 458.661 & 0.446 & 0.000 \\
\hline
\end{tabular}

Note: All bolded values denote statistical significance at least at 5 percent level. Adj. $R^{2}$ - Adjusted R-squared, CISS - Composite Indicator of Systemic Stress, EU Index -- FTSE Europe, NEER - Nominal Effective Exchange Rate, OIL -- price of oil, US-1M -- United States 1-Month Bond Yield.

Source: Authors' calculations. 
significant coefficients for both the stock market indices and at the US 1-Month Bond Yield. Repeatedly, this situation is the same as in the no effects panel specification.

Estimating our equation in the period fixed effects specification, we did not find statistically significant regression coefficients for the price of oil, but we did find for the other variables. For example, we notice significant coefficients for the local stock market index and the CISS. Removing the local stock market index from the equation, we find statistically significant regression coefficients for the NEER. Then, estimating the equation without the European index, we discover significant coefficients for the local stock market index and for the CISS. Excluding both stock market indices from our equation, we find significant regression coefficients for the NEER. And finally, estimating the equation without the NEER, we notice significant coefficients for the local stock market index and for the CISS.

The last panel specification has both cross-section and period fixed effects. This represents a combination of the second and the third panel specifications. In this case, similar to the period fixed effects specification, we did not notice statistically significant regression coefficients for the oil price. Including all variables in the equation, we notice significant coefficients for the local stock market index and for the CISS. Eliminating the local stock market index from our equation, we discover significant coefficients only for the NEER. Next, estimating the equation without the European index, we notice significant coefficients for the local stock market index and for the CISS. Excluding both stock market indices from our equation, we find significant regression coefficients only for the NEER. Finally, estimating the equation without the NEER, the results show significant coefficients for the local stock market index and for the CISS.

The results we obtain are consistent concerning the coefficients signs, regardless of the panel specification. Thus, the exposure of Eastern European financial companies' risk-adjusted returns to changes in oil prices is positive, as well as the exposure to local and European market risks (through the two indices included in our panel estimation) and to changes in NEER. They indicate that stock market investors incorporate higher oil prices, the overall depreciation of the domestic currencies and higher values of the stock indices into higher risk-adjusted returns of financial companies. At the same time, the exposure to the US interest rates is, as expected, negative, as well as the exposure to CISS; the latter suggests that higher perceived levels of systemic stress depress risk-adjusted returns of financial companies, which is an expected result. At the same time, financial companies' returns to the local stock index is very stable in all panel specifications, but the other identified exposures change their values and even signs depending on the specification; specifically, when the period fixed effects specification 
is used. This might indicate that the period used in our research has particularities that have impacted differently financial companies from our sample of countries; in this framework, we notice the increase in the coefficients' values for CISS when the period fixed effect panel specification is introduced. We could interpret this result as an increased exposure of financial companies to a higher level of systemic risk after 2010.

Comparing the panel specifications from the perspective of oil price exposure, we notice that in the case of period fixed effects and in the case of cross-section and period fixed effects panel specifications, the oil price did not show significant coefficients. This suggests that there are considerable company and period-related idiosyncrasies that alter the exposure of financial companies to oil prices changes.

Summarizing the results, we consider the most important result of our research the fact that oil price showed statistically significant coefficients. This variable displayed significant coefficients only when we excluded from the equation the local stock market index or the European stock market index or both.

Taking into consideration the values of the Adjusted R-squared and the values of the S.E. of regression, we prefer the cross-section and period fixed effects panel specification that excludes from the equation the NEER. The value of the Adjusted R-squared is the highest and the value of the Standard Error of the regression is the lowest at this type of panel and for this reason we consider it the best panel specification from our model.

\section{Conclusion}

The aim of our research is to investigate the exposure to oil price changes of financial companies listed on stock exchanges from eight Eastern European countries. Using monthly datasets covering the period from February 2010 to February 2018, we examine the relationship between stock prices of these financial companies, oil prices and other macroeconomic variables, such as local stock indices, a European stock index (FTSE Europe), NEER, interest rates and CISS.

The overall results suggest that oil price changes impact and influence the stock prices of financial companies from Eastern European countries. The oil price had a higher impact on the stock prices of financial companies than we expected and it proved be a risk factor for the financial sector. Our results indirectly highlight the pervasive exposure of economies from Eastern Europe to risk factors through the financial sector channels, which raises serious challenges from the perspective of macroeconomic and financial policies. Oil shocks might impact the adequacy of central banks' foreign 
currency reserves and oil importers will experience bigger current deficit and costpush inflation. In other words, persistently high oil prices could affect these economies through their impact on external balances, on inflation, on monetary or exchange rate policies, and as well on fiscal balances. The government should take into consideration another energy sources in the near future.

Moreover, for investors, the significant relationship between oil price changes and financial companies' stock prices could help in order to build efficient portfolio investment strategies. They should take into consideration this significant relationship.

An interesting possible future direction of research would be to investigate in detail the channels through which the transmission from oil prices changes to the Eastern Europe economy could operate. Also, maybe another methodology should be used in order to capture the existence of other unexpected and interesting relationships.

\section{References}

[1] Khandelwal, P., Miyajima, K. and Santos, A. (2016). The Impact of Oil Prices on the Banking System in the GCC. IMF Working Paper WP/16/161, International Monetary Fund. Washington, DC.

[2] The official website of Eurostat, https://ec.europa.eu/eurostat/

[3] Barjaktarovic, L., Paunovic, M. and Jecmenica, D. (2013). Development of the Banking Sector in CEE Countries -- Comparative Analysis. Journal of Central Banking Theory and Practice, vol. 2, pp. 93-114.

[4] Hamilton, D.J. (1983). Oil and the macroeconomy since World War II. The Journal of Political Economy, vol. 9, pp 228-248.

[5] Hamao, Y. (1988). An empirical examination of the arbitrage pricing theory: using Japanese data. Japan and the World Economy, vol. 1, pp 45--61.

[6] Kaneko, T. and Lee, B.S. (1995). Relative importance of economic factors in the U.S. and Japanese stock markets. Journal of the Japanese and International Economies, vol. 9, no. 3, pp 290-307.

[7] Huang, R.D., Masulis, R.W. and Stoll, H.R. (1996). Energy shocks and financial markets. Journal of Futures Market, vol. 16, pp 1--27.

[8] Jones, C.M. and Kaul, G. (1996). Oil and the stock markets. The Journal of Finance, vol. 51, pp 463--491.

[9] Cong, R.G., Wei, Y.M, Jiao, J.L, et al. (2008). Relationships between oil price shocks and stock market: An empirical analysis from China. Energy Policy, vol. 36, pp 35443553. 
[10] Jammazi, R. and Aloui, C. (2010). Wavelet decomposition and regime shifts: Assessing the effects of crude oil shocks on stock market returns. Energy Policy, vol. 38, no. 3, pp 1415-1435.

[11] Sadorsky, P. (1999). Oil price shocks and stock market activity. Energy Economics, vol. 21, pp 449--469.

[12] Ciner, C. (2001). Energy shocks and financial markets: nonlinear linkages. Studies in Nonlinear Dynamics and Econometrics, vol. 5, pp 1079-1079.

[13] Arouri, M.E. and Nguyen, D.K. (2010). Oil prices, stock markets and portfolio investment: evidence from sector analysis in Europe over the last decade. Energy Policy, vol. 38, no. 8, pp 4528-4539.

[14] Arouri, M.E. (2011). Does crude oil move stock markets in Europe? A sector investigation. Economic Modelling, vol. 28, pp 1716--1725.

[15] Degiannakis, S., Filis, G. and Floros, C. (2013). Oil and stock returns: Evidence from European industrial sector indices in a time-varying environment. Journal of International Financial Markets, Institutions and Money, vol. 26, pp 175-191.

[16] Elyasiani, E., Mansur, I. and Odusami, B. (2011). Oil price shocks and industry stock returns. Energy Economics, vol. 33, no. 5, pp 966-974.

[17] Narayan, P. K. and Sharma, S. S. (2011). New evidence on oil price and firm returns. Journal of Banking and Finance, vol. 35, no.12, pp 3253-3262.

[18] Scholtens, B. and Yurtsever, C. (2012). Oil price shocks and European industries. Energy Economics, vol. 34, pp 1187-1195.

[19] Gogineni, S. (2010). Oil and the stock market: an industry level analysis. Financial Review, vol. 45, pp 995-1010.

[20] Asteriou, D. and Bashmakova, Y. (2013). Assessing the impact of oil returns on emerging stock markets: A panel data approach for ten Central and Eastern European Countries. Energy Economics, vol. 38, pp 204--211.

[21] Mohanty, S., Nandha, M. and Bota, G. (2010). Oil shocks and stock returns: The case of the Central and Eastern European (CEE) oil and gas sectors. Emerging Markets Review, vol. 11, pp 358-372.

[22] Akinlo, T. and Apanisile, O.T. (2015). The Impact of Volatility of Oil Price on the Economic Growth in Sub-Saharan Africa. British Journal of Economics, Management \& Trade, vol. 5, no. 3, pp 338-349.

[23] Santillán-Salgado, R., Calderón-Villarreal, C. and Venegas-Martínez, F. (2017). Impact of Oil Prices on Stock Markets in Major Latin American Countries (2000-2015). International Journal of Energy Economics and Policy, vol. 7, no. 4, pp 205-215. 
[24] Faff, R.W. and Brailsford, T.J. (1999). Oil price risk and the Australian stock market. Journal of Energy Finance \& Development, vol. 4, no. 1, pp 69-87. 